\title{
PENGARUH KEMASAN DAN KESADARAN MEREK TERHADAP KEPUTUSAN PEMBELIAN KUE NILAM SARI DI BANDUNG
}

Satria Indra Praja Persada

Satriapraja3@gmail.com

\begin{abstract}
Abstrak
Dalam Era Globalisasi banyak perusahan yang bersaing dalam pasar sehingga perusahaan perusahaan tersebut berebut perhatian konsumen dengan berbagai cara salah satunya adalah membuat kemasan yang dapat menarik konsumen, selain kemasan adapula kesadaran produk dimana kedua hal ini dapat mempengaruhi keputusan konsumen dalam membeli sebuah produk.akibat terjadinya penurunan penjualan produk Nilamsari penurunan penjualan ini mengindikasikan bahwa ada beberapa faktor yang membuat konsumen tidak melakukan keputusan pembelian setelah dilakukan observasi, wawancara dan survey mengindikasikan beberapa faktor yang terkandung dalam produk Nilamsari yaitu kemasan dan kesadaran merek konsumen akan produk Nilamsari masih kurang sehingga dibutuhkan sebuah Penelitian yang bertujuan untuk mengetahui tanggapan konsumen nilamsari, mengenai kemasan produk, kesadaran merek dan keputusan pembelian dan pengaruh dari variabel - variabel tersebut. Dalam penelitian ini digunakan berbagai metode seperti metode deskriptif dan verifikatif . Unit Analisis penelitian ini adalah konsumen produk Nilamsari yang berjumlah 270 responden . Pengujian Statistik yang digunakan adalah Path Analysis dan menggunakan bantuan program aplikasi Lisrel ver 8.72 Dari analisis data hasil yang diperoleh yaitu koefisien korelasi sebesar 0,35. Hal ini menunjukan adanya korelasi positif antara kemasan, kesadaran merek terhadap keputusan pembelian . Dengan besar pengaruh 35\%. Penelitian ini membuktikan bahwa kemasan , kesadaran merek berpengaruh signifikan terhadap keputusan pembelian konsumen terhadap produk kue Nilamsari
\end{abstract}

\section{Keyword : Kemasan , Kesadaran Merek , Keputusan Pembelian}

\begin{abstract}
In the era of globalization, more companies competing in the market so that the company the company for the attention of consumers in many ways one of which is to make packaging that can attract consumers, in addition to awareness unisex packaging products where both of these things can affect the consumer's decision to purchase an occurrence produk.because decrease in product sales Nilamsari sales decline, indicating that there are several factors that make consumers do not make purchasing decisions after observation, interviews and surveys indicate some of the factors contained in the packaging and product Nilamsari consumer brand awareness for products Nilamsari still less so it takes a research aims to determine consumer responses nilamsari, on product packaging, brand awareness and purchase decisions and influence of variables - those variables. This study used a variety of methods such as descriptive and verification methods. Unit of analysis of this research is Nilamsari consumer products totaling 270 respondents. The test statistics used are using Path Analysis and application program support lisrel ver 8.72 From the data analysis of the results obtained by the correlation coefficient of 0.35. This shows a positive correlation between the packaging, brand awareness on purchasing decisions. With the influence of 35\%. This study proves that the packaging, brand awareness significantly influence the purchasing decisions of consumers towards the product cake

Nilamsari
\end{abstract}

\section{Keyword: Packaging, Brand Awareness, Purchase Decision}




\section{Pendahuluan}

Di era globalisasi saat ini, perusahaan dituntut agar bisa menciptakan sebuah produk yang memiliki daya saing dengan produk yang lain agar dapat bertahan di dalam arus persaingan bisnis. Banyaknya pesaing baru yang bermunculan dengan berbagai macam cara dan strategi baru membuat persaingan semakin ketat. Suatu perusahaan harus dapat memenangkan persaingan tersebut dan dapat mempertahankan bisnisnya tersebut. Di Indonesia sendiri banyak perusahaan bermunculan, dengan banyaknya perusahaan yang bermunculan, membuat persaingan bisnis semakin ketat.

Indonesia memiliki pasar yang potensial dalam berbisnis, dengan banyaknya jumlah penduduk indonesia, banyak perusahaan baik perusahaan dalam negeri maupun asing berusaha mendirikan usaha bisnis dan menciptakan produk yang memiliki jenis dan varian yang bermacammacam. Para perusahaan tersebut berlombalomba menambah nilai produk tersebut agar terlihat menarik sehingga para konsumen memutuskan untuk membeli produk yang perusahaan tersebut tawarkan. Hal ini diperlukan agar konsumen tertarik membeli produk yang ditawarkannya, sehingga perusahaan tersebut dapat bertahan dalam persaingan bisnis yang semakin ketat.

Salah satu cara untuk menarik para konsumen adalah dengan cara membuat desain kemasan yang baik sehingga dapat menarik konsumen untuk membeli produk tersebut. Desain kemasan sendiri sangat penting bagi suatu produk, karena selain melindungi produk tersebut, dalam sebuah kemasan produk tercantum berbagai macam informasi mengenai produk tersebut, dan membuat produk tersebut memiliki sebuah identitas dalam suatu pasar sehingga produk memberikan diferensiasi dengan produk yang lainnya dan dapat menimbulkan kesadaran merek bagi konsumen sehingga produk tersebut dapat selalu ada di benak konsumen. Menurut Aaker (1992: 61) dalam Farli Liwe (2013: 2019) konsumen akan membeli merek yang dia kenal oleh sebab itu kesadaran merek penting dimiliki sebuah brand atau merek.

Kesadaran merek atau brand awareness sendiri menurut Aaker (1992: 61) dalam Farli Liwe (2013: 2019) adalah kondisi seseorang konsumen tahu dan sadar mengenai keberadaan sebuah produk di pasaran dengan sendirinya tanpa harus diberi pancingan-pancingan tertentu mengenai sebuah kategori sebuah merek. Kesadaran merek adalah kemampuan dari seorang pembeli potensial untuk mengenali atau memanggil ulang (mengingat) bahwa sebuah merek adalah bagian dari sebuah kategori produk tertentu. Oleh sebab itu kesadaran merek itu merupakan salah satu faktor penting dalam memasarkan sebuah produk, karena apabila konsumen memiliki kesadaran merek sebuah produk dan produk tersebut ada didalam benak konsumen maka brain awareness dapat mempengaruhi konsumen dalam memutuskan keputusan pembelian suatu produk.

Ketika membeli produk, secara umum konsumen akan melakukan pengambilan keputusan pembelian. Keputusan pemnbelian dapat diartikan sebagai suatu proses pemilihan alternatif pilihan yang dihadapi oleh seseorang dalam konteks jenis pilihan konsumsi, mulai dari pemakaian produk baru sampai ke pemakaian produk lama dan sudah dikenal luas (Schiffman dan Kanuk, 2008: 485). Dengan pernyataan ini jelas bahwa konsumen cenderung akan memilih merek yang dikenalnya dalam memutuskan sebuah keputusan pembelian. Sayangnya banyak sekali perusahaan-perusahaan kecil, khususnya di kota Bandung belum menyadari pentingnya membangun kesadaran merek. Padahal dengan mereka membangun kesadaran merek pada konsumen akan membuat produknya lebih banyak diminati pasar sehingga produknya dapat terjual banyak dipasaran. Apalagi di hadapkan dengan Bandung yang memiliki lokasi strategis, dengan dibangunnya tol 
Jabodetabek banyak turis Jakarta datang ke Bandung untuk berwisata ini dapat menjadi sebuah potensi bagi para produsen Bandung untuk menjual produk buatannya.

Menurut Kepala Divisi Pemasaran Dinas Pariwisata dan Kebudayaan Kota Bandung, Kenny Dewi Kanisari (2013: 01) dalam kompas mengemukakan bahwa jumlah kedatangan turis asing maupun turis lokal di Bandung pada 2013 mencapai 4,9 juta. Dengan banyaknya kunjungan wisatawan ke Bandung, menjadikan Bandung sebagai lahan potensial bagi perusahaan, baik perusahaan besar, kecil maupun mikro dalam memasarkan produk perusahaannya mulai dari pakaian, makanan, dan lain-lain.

Bandung memiliki banyak industri yang bergerak di industri makanan mulai dari makanan tradisional, modern hingga makanan ringan seperti kripik, kue dan jajanan lainnya yang banyak sekali berkembang di Bandung. Fenomena ini didasari dari banyaknya kunjungan wisatawan ke kota Bandung khususnya wisatawan dari wilayah Jabodetabek yang selalu memadati Bandung pada akhir pekan menjadikan Bandung sebagai lahan potensial bagi para pedagang, khususnya pedagang kue yang menjadikan kue buatannya oleh-oleh disaat mereka kembali ke rumah.

Nilamsari merupakan sebuah perusahaan yang bergerak di bidang pembuatan makanan kue yang memiliki target pasar wisatawan yang datang ke Bandung, dan menjadikan Nilamsari menjadi sebagai oleh-oleh. Nilamsari sendiri merupakan perusahaan yang berdiri pada tahun 2008 dan bergerak di bidang pembuatan kue. Nilamsari memproduksi berbagai macam kue seperti Proll Tape, Brownies dan kue kering. Namun menurut Dian S Fuadiyah sebagai pemilik Nilamsari mengemukakan bahwa terjadi penurunan penjualan kue dari tahun ke tahun sehingga perusahaannya terancam bangkrut berikut adalah data penjualan produk Nilamsari.
Chart Title

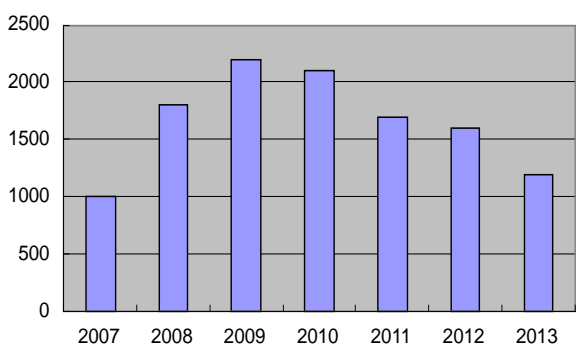

Gambar 1.1.

Jumlah Penjualan Produk

Sumber: Buku Penjualan Nilamsari

Menurut wawancara kepada Dian S Fuadiyah selaku pemilik dari Nilamsari salah satu faktor terjadinya penurunan penjualan Nilamsari terjadi karena munculnya banyak pesaing, salah satunya perusahaan ternama yang memunculkan produk dengan jenis yang sama dengan Nilamsari. Dengan banyaknya pembeli yang beralih memutuskan membeli produk pesaing dan tidak memutuskan untuk melakukan pembelian terhadap produk tersebut dapat memicu turunnya penjualan pada produk Nilamsari. Sehingga penurunan penjualan ini berhubungan langsung dengan keputusan pembelian, yang kurang terhadap produk dari Nilamsari. Untuk mengatasi masalah itu, lalu berangkat dari hasil wawancara dan asumsi tersebut. Penulis melakukan survey awal kepada 30 responden mengenai keputusan pembelian.

\section{Hasil Kuesioner Survey Awal Keputusan Pembelian Tahun 2014}

\begin{tabular}{|c|c|c|c|c|}
\hline \multirow{2}{*}{ Pertanyaan } & \multicolumn{3}{|c|}{ Alternatif Jawaban } \\
\cline { 2 - 5 } & \multicolumn{2}{|c|}{ Ya } & \multicolumn{2}{c|}{ Tidak } \\
\cline { 2 - 5 } & F & \% & F & \% \\
\hline $\begin{array}{c}\text { Saya selalu } \\
\text { menginginkan Produk } \\
\text { Nilamsari }\end{array}$ & 12 & 40 & 18 & 60 \\
\hline $\begin{array}{c}\text { Produk Nilamsari lebih } \\
\text { bagus dari produk } \\
\text { lainnya }\end{array}$ & 9 & 30 & 19 & 70 \\
\hline $\begin{array}{c}\text { Saya sering mencari tahu } \\
\text { informasi produk terbaru } \\
\text { dari Nilamsari }\end{array}$ & 8 & 27 & 22 & 73 \\
\hline
\end{tabular}




\begin{tabular}{|c|c|c|c|c|}
\hline $\begin{array}{c}\text { Keputusan Pembelian } \\
\text { (Total) }\end{array}$ & 32 & 35 & 58 & 65 \\
\hline
\end{tabular}

Sumber: Hasil kuesioner Survey Awal Keputusan Pembelian Tahun 2014

Dilihat dari tabel keputusan pembelian mengindikasikan sekitar 35\% responden menyatakan Ya dan $65 \%$ responden menyatakan Tidak. Dari hasil diatas dapat diambil kesimpulan bahwa persepsi seseorang dalam mengambil keputusan pembelian terhadap produk Nilamsari kurang baik. Dimana dengan tidak banyaknya orang melakukan keputusan pembelian pada produk Nilamsari mendasari turunnya penjualan produk Nilamsari, sehingga jika di biarkan lamakelamaan harus menutup bisnisnya. Lalu penulis melakukan observasi ke lapangan guna mencari penyebab turunnya keputusan pembelian masyarakat mengenai masalah ini.

kemasan adalah salah satu faktor penting bagi konsumen saat melakukan keputusan pembelian seperti yang diutarakan oleh Dhar (2007) dalam Astri dan Zalfiana $(2011,12)$ packaging plays an important role at this meeting point (also known as the point of purchase), as this is the most important point of interaction between brands and consumers; it is at this stage that consumers decide which brands to purchase. Kemasan memegang peranan penting pada titik pertemuan ini (juga dikenal sebagai titik pembelian), karena ini adalah titik paling penting dari interaksi antara merek dan konsumen; itu pada tahap ini bahwa konsumen memutuskan untuk membeli merek.

Mengenai Kemasan Produk penulis mewawancarai Dian S Fuadiyah sebagai pemilik Nilamsari menyatakan, bahwa produk Nilamsari belum pernah mengganti kemasan produk tersebut dan selama ini hanya membeli kemasan yang sudah tersedia di pasaran.

Dari hasil observasi ke lapangan penulis menemukan beberapa kelemahan dalam produk Nilamsari yang mendasari berkurangnya orang melakukan keputusan pembelian, yaitu produk Nilamsari memiliki kemasan sama dengan produk lain dan kurangnya kesadaran merek konsumen akan merek Nilamsari. Dan dengan asumsi ini mendasari penulis melakukan survey. Survey awal dilakukan kepada 30 Responeden mengenai Kemasan Produk dan Kesadaran Merek Dengan Asumsi awal tersebut penulis melakukan survey awal mengenai Kemasan.

Hasil Kuesioner Survey Awal Kemasan Tahun 2014

\begin{tabular}{|l|c|c|c|c|}
\hline \multirow{2}{*}{ Pertanyaan } & \multicolumn{4}{c|}{ Alternatif Jawaban } \\
\cline { 2 - 5 } & \multicolumn{2}{|c|}{ Ya } & \multicolumn{2}{c|}{ Tidak } \\
\cline { 2 - 5 } & F & \% & F & \% \\
\hline $\begin{array}{l}\text { Bentuk dari kemasan } \\
\text { Nilamsari unik }\end{array}$ & 12 & 40 & 18 & 60 \\
\hline $\begin{array}{l}\text { Warna dari kemasan } \\
\text { Nilamsari menonjol }\end{array}$ & 8 & 27 & 22 & 73 \\
\hline $\begin{array}{l}\text { Material yang digunkan } \\
\text { untuk mengemas produk } \\
\text { Nilamsari terlihat } \\
\text { berkualitas }\end{array}$ & 14 & 46 & 16 & 54 \\
\hline $\begin{array}{l}\text { Kemasan Produk } \\
\text { (Total) }\end{array}$ & 34 & 38 & 56 & 62 \\
\hline
\end{tabular}

Sumber: Hasil Kuesioner Survey Awal

Kemasan Tahun 2014

Berdasarkan hasil survey yang telah dilakukan penulis disana terlihat bahwa persentase Tidak lebih besar daripada persentase Ya, sehingga ini mengindikasikan bahwa kemasan produk kue Nilamsari kurang baik.

Dalam memutuskan pembelian seorang konsumen, merek pun tidak luput menjadi sebuah pertimbangan seperti yang diutarakan oleh Kottler (2013:181). In general, the consumer purchase decision is to buy the most preferred brand. Pada umumnya, keputusan pembelian konsumen adalah membeli merek yang paling disukai.

Menurut dari hasil wawancara penulis dengan beberapa pembeli produk Nilamsari dasar mereka dalam memutuskan pembelian produk Nilamsari adalah karena 
Produk Nilamsari memberikan keju dan kismis lebih banyak daripada merek lain, dengan kata lain merek kurang memiliki kesadaran merek terhadap produk Nilamsari , karena mereka memutuskan membeli kue karena kue tersebut memberikan keju dan kismis lebih banyak bukan karena merek.

Dan dari aspek ini diketahui bahwa Kesadaran Merek Nilamsari sendiri tergolong rendah hal ini diketahui dari hasil Survey awal lapangan sebagai berikut.

\begin{tabular}{|c|c|c|c|c|}
\hline \multirow{3}{*}{ Pertanyaan } & \multicolumn{4}{|c|}{ Alternatif Jawaban } \\
\hline & \multicolumn{2}{|c|}{ Ya } & \multicolumn{2}{|c|}{ Tidak } \\
\hline & $\mathbf{F}$ & $\%$ & $\mathbf{F}$ & $\%$ \\
\hline $\begin{array}{l}\text { Nilamsari mengeluarkan } \\
\text { bakpia sebagai produk } \\
\text { terbarunya }\end{array}$ & 14 & 46 & 16 & 44 \\
\hline $\begin{array}{l}\text { Merek Nilamsari } \\
\text { merupakan produk kue } \\
\text { yang terlintas di pikiran } \\
\text { saya }\end{array}$ & 8 & 26 & 22 & 64 \\
\hline $\begin{array}{l}\text { Nilamsari merupakan } \\
\text { Merek kue terkenal }\end{array}$ & 9 & 30 & 21 & 70 \\
\hline $\begin{array}{l}\text { Kesadaran Merek } \\
\text { (Total) }\end{array}$ & 31 & 35 & 59 & 65 \\
\hline
\end{tabular}

Sumber: Hasil Kuesioner Survey Awal Kesadaran Merek Tahun 2014

Dilihat dari Tabel Kesadaran produk terlihat hasil jawaban Ya sebesar 35\% dan Tidak sebesar 65\%, sehingga dengan banyaknya responden yang menjawab Tidak ini mengindikasikan bahwa tingkat kesadaran merek konsumen akan produk tersebut rendah. Sedangkan menurut Kotler dan Armstrong, dengan kata lain Kesadaran Merek sangat berpengaruh kepada keputusan pembelian seseorang.

Dari latar belakang tersebut menunjukan adanya indikasi bahwa penurunan pembelian produk Nilamsari didasari dari ketidaksadaran masyarakat terhadap produk Nilamsari dan Nilamsari tidak memiliki kemasan yang dapat membedakannya dengan produk yang lain, sehingga produk tersebut tidak menarik pembeli untuk melakukan keputusan pembelian.

Dengan latar belakang tersebut penulis merasa tertarik untuk melakukan penelitian dengan mengambil judul: "Pengaruh Kemasan dan Pembentukan Brand Awareness terhadap Keputusan Pembelian Nilamsari di Bandung."

\section{Kajian Pustaka, Kerangka Pemikiran dan Hipotesis}

\subsection{Kajian Pustaka}

Dalam dunia bisnis terdapat persaingan untuk dapat perhatian dari konsumen sehingga dibutuhkan sebuah pemasaran yang baik agar produk dapat terjual dengan baik.

Pemasaran adalah lingkup yang luas dalam dunia bisnis, terdapat didalamnya strategi internal maupun eksternal perusahaan yang dapat mempengaruhi sukses atau tidaknya sebuah perusahaan.

Pemasaran (marketing) menurut Kotler dan Keller (2012: 5), "Marketing is the activity, set of institutions, and processes for creating, communicating, delivering, and exchanging offerings that have value for customers, clients, partners, and society at large." Sejalan dengan hal tersebut pemasaran menurut Tjiptono (2008: 5) adalah "fungsi yang memiliki kontak yang paling besar dengan lingkungan eksternal, padahal perusahaan hanya memiliki kendali yang terbatas terhadap lingkungan eksternal".

Payne (2007: 27) menyatakan bahwa: "pemasaran merupakan suatu proses mempresepsikan, memahami, menstimuli dan memahami kebutuhan pasar sasaran yang dipilih secara khusus dengan menyalurkan sumber-sumber sebuah organisasi untuk memenuhi kebutuhankebutuhan tersebut". Payne membagi fungsi pemasaran menjadi tiga komponen kunci yaitu: 
1. Bauran pemasaran: Unsur atau elemen internal penting yang membentuk program pemasaran sebuah organisasi.

2. Kekuatan pasar: Peluang dan ancaman eksternal dimana operasi-operasi pemasaran sebuah organisasi berinteraksi.

3. Proses penyelarasan: Proses strategik dan manajerial untuk memastikan bahwa bauran pemasaran dan kebijaksanaan internal baik bagi kekuatan pasar.

Dari ketiga penjelasan para ahli diatas jika dibaca secara seksama ada keterkaitan antara toeri satu dengan yang lainya mengenai pemasaran diatas, dimana pemasaran merupakan sebuah nilai yang memiliki fungsi yang besar baik secara internal maupun eksternal perusahaan yang harus bisa dirancang sedemikian rupa oleh perusahaan dalam menangkap kebutuhan pelanggan/pasar untuk memaksimalkan segala profit perusahaan.

Dalam pemsaran dikenal bauran pemasaran bauran pemasaran menurut Alma (2008: 303) dalam Valdy Ronald Wowor (2013: 1231) mendefinisikan bauran pemasaran yang digunakan dalam analisis adalah konsep 7P yang terdiri dari 4P tradisonal, yaitu: Produk (Product), Harga (Price), Lokasi (Place), dan Promosi (Promotion). Ditambah dengan 3P khusus untuk pemasran jasa, yaitu: SDM (People), Bukti Fisik/ Sarana dan Prasarana (Physical Evidence), dan Proses (Process). Marketing mix menurut Assauri (2011:198) adalah kombinasi variabel atau kegiatan yang merupakan inti dari system pemasaran, variabel yang dapat dikendalikan oleh perusahaan untuk mempengaruhi reaksi para pembeli atau konsumen.

Salah satu bagian dari bauran pemasaran adalah produk menurut Tjiptono (2004: 95) dalam Valdy Ronald Wowor $\mathbf{( 2 0 1 3 , 1 2 3 1 )}$ menyatakan produk merupakan segala sesuatu yang ditawarkan produsen untuk diperhatikan, diminta, dicari, dibeli, digunakan, atau dikonsumsi pasar sebagai pemenuhan kebutuhan atau keinginan pasar yang bersangkutan. Kotler \& Amstrong (2006: 266) menyatakan produk adalah semua hal yang dapat ditawarkan kepada pasar untuk menarik perhatian, akuisisi, penggunaan, atau konsumsi yang dapat memuaskan suatu keinginan atau kebutuhan.

Dan dalam sebuah produk terdapat attribut - attribut yang disebut attribut produk Menurut Tjiptono (2008: 103) dalam Hizkia B. Anis S.L.H.V Joyce Lapian Peggy A. Mekel mengatakan atribut produk adalah unsur-unsur produk yang dipandang penting oleh konsumen dan dijadikan dasar pengambilan keputusan pembelian. Atribut produk meliputi merek, kemasan, jaminan (garansi), pelayanan dan sebagainya. Atribut produk berperan sebagai identitas, alat promosi (pemberi daya tarik dan informasi), cerminan inovasi, alat membina citra (jaminan kualitas) dan alat mengendalikan pasar. Pengembangan suatu produk atau jasa melibatkan pendefinisian manfaat yang akan ditawarkan produk dan jasa tersebut. Manfaat ini dikomunikasikan dan dihantarkan oleh atribut produk. Kotler dan Armstrong (2008: 272) mengatakan terdapat beberapa macam atribut produk yakni, kualitas produk, fitur produk, gaya dan desain produk.

Salah satu atribut produk adalah citra merek Menurut Susanto (2004: 24) dalam Christian Lasander (2013, 285). Citra merek adalah apa yang dipersepsikan oleh konsumen mengenai sebuah merek. Dimana hal ini menyangkut bagaimana seorang konsumen menggambarkan apa yang mereka pikirkan mengenai sebuah merek dan apa yang mereka rasakan mengenai merek tersebut ketika mereka memikirkannya.

\subsubsection{Kemasan}

\subsubsection{Pengertian Kemasan}


Menurut Kotler (2013 : 200) packaging is the activity of designing and producing the container or wrapper as a product.pengemasan adalah kegiatan merancang dan memproduksi wadah atau bungkus sebagai sebuah produk.

\subsubsection{Fungsi Kemasan}

Menurut Klimchuck \& Krasovec (2007) dalam Astri Cahyorini dan Effey Zalfiana Rusfian $(2010,11)$ : the packaging design's function is to visually communicate product differences. In the competitive market of today, packaging design becomes a brand's promotional vehicle, highlighting its position on the shelf, artinya fungsi desain kemasan adalah untuk berkomunikasi secara visual perbedaan produk. Dalam pasar yang kompetitif saat ini, desain kemasan menjadi kendaraan promosi merek, menyoroti posisinya di rak.

\subsubsection{Indikator Kemasan}

Dalam Jurnal Rita Kuvykaite, Aiste Dovaliene,Laura Navickiene $(2009,442)$ menuliskan beberapa Indikator atau elemen dari kemasan dari berbagai ahli yaitu adalah:

Kotler (2003) distinguishes six elements that according to him must be evaluated when emploing packaging decisions: size, form, material, colour, text and brand. Kotler (2003) membedakan enam elemen yang menurutnya harus dievaluasi ketika emploing keputusan kemasan: ukuran, bentuk, bahan, warna, teks dan merek.

Vila \& Ampuero (2007) similar to Underwood (2003) distinguished two blocks of package elements: graphic elements (colour, typography, shapes used, and images) and structural elements (form, size of the containers, and materials). It should be noticed that these two blocks, similar to classification of Smith \& Taylor (2004) do not include verbal elements of package.Vila \& Ampuero (2007) mirip dengan Underwood (2003) membedakan dua blok dari elemen paket: elemen grafis (warna, tipografi, bentuk yang digunakan, dan gambar) dan elemen struktur (bentuk, ukuran kontainer, dan bahan). Perlu diperhatikan bahwa kedua blok, mirip dengan klasifikasi Smith \& Taylor (2004) tidak memasukkan unsur verbal paket.

Silayoi \& Speece $(2004 ; 2007)$ divide package into two categories of elements: visual elements (graphics, colour, shape, and size) and informational elements (information provided and technology). According to Silayoi \& Speece (2004) visual elements are related with affective aspect of consumer's decision making process, while informational elements are related with cognitive one. Silayoi \& Speece $(2004$; 2007) paket dibagi menjadi dua kategori elemen: elemen visual (grafik, warna, bentuk, dan ukuran) dan unsur-unsur informasi (informasi yang diberikan dan teknologi). Menurut Silayoi \& Speece (2004) unsur-unsur visual yang berkaitan dengan aspek afektif dari proses pengambilan keputusan konsumen, sementara unsur-unsur informasi yang terkait dengan satu kognitif.

Dari beberapa pendapat diatas penulis memilih untuk mengambil pendapat dari Kottler, karena sesuai dengan objek penelitian yang akan diteliti.

\subsubsection{Brand Awareness}

\subsubsection{Pengertian Brand \\ Awareness}

Menurut Aaker (1991, 61 ) dalam Rinal B. Shah $(2012,50)$ dan Philander Varian Massie $(2013,1474)$ juga (Rangkuti, 2002:39). Brand awareness is "the ability of potential buyer to recognize or recall that a brand is a member of a certain 
product category". Brand awareness merupakan kesanggupan seorang calon pembeli untuk mengenali atau mengingat kembali bahwa suatu merek merupakan bagian dari kategori merek tertentu (Aaker, 1996:90).

Menurut Terence A.Shimp (2003:11) dalam Jefri Heridiansyah (2012,56) mengemukakan bahwa brand awareness merupakan kemampuan sebuah merek untuk muncul dalam benak konsumen ketika mereka sedang memikirkan kategori produk tertentu dan seberapa mudahnya nama tersebut dimunculkan.

Jadi tingkat Brand Awareness dapat diukur dengan melihat bagaimana sebuah merek tersebut dapat dengan mudah dikenali dan diingat kembali oleh seorang konsumen. Biasanya untuk mendapatkan tingkat Brand Awareness yang tinggi maka perusahaan harus dapat mengikat emosi konsumen denganberbagai komunikasi pemasaran, atribut dan nilai dari produk tersebut yang berkenaan secaraemosional dengan konsumen (Emotional Bonding). Brand Awareness adalah bagian dari sebuah brand equity, dan Brand Awareness adalah sebuah tingkat dimana sebuah merek yang dulu tidak dikenal menjadi dikenal sekarang.

\subsubsection{Tingkatan dalam Brand \\ Awareness}

Brand Awareness sendiri mempunyai empat tingkatan untuk dapat membentuk suatu nilai didalambenak calon konsumen. Menurut Aaker dan Simamora dalam Haryanto (2009) empat tingkatan tersebut adalah:

Pertama: Tidak menyadari merek (Brand Unaware) pada tingkat ini konsumen tidak sadar akan keberadaan merek-merek di pasaran, dan didalam benaknya semua merek adalah sama dengan tidak mempedulikan kualitas dari merek tersebut.
Kedua: Pengenalan merek (Brand Recognition) padatingkat ini konsumen mampu untuk mengenali merek dan memberikan nama merek sebagai petunjuk,dengan diberikan rangsangan yang cukup besar mengenai satu kategori produk tertentu.

Ketiga: Pengingatan kembali merek (Brand Recall) pada tingkat ini konsumen konsumen tidak perlu diberikansuatu rangsangan untuk menyebutkan merekmerek tertentu didalam pasaran.

Keempat: Puncak pikiran (Top of Mind) adalah merek yang pertama kali muncul didalam benak seorang konsumen dandisebutkan ketika ditanya mengenai sebuah kategori produk yang ada di pasaran.

\subsubsection{Indikator Brand}

\section{Awareness}

Menurut Philander Varian Massie (2013, 1477) Indicator Brand Awareness terdiri dari: Ingatan merek, pengenalan merek, hubungan simbol dengan merek.

Menurut Chieng Fayrene Y.L. \& Goi Chai Lee, (2011, 36) menggabungkan semua model brand awareness dari berbagai peneliti yaitu (Aaker 1991, Kapferer 1991, Keller 1992, Agarwal and Rao 1996, Krishnan 1996, Na, Marshall and Keller 1999,Menyebutkan bahwa brand awareness memiliki indicator Brand Recall ,Brand Recognition, Top of Mind, Brand Dominance, Brand Knowledge, Brand Opinion.

Jika dilihat dari dua Indicator diatas penulis memilih indikator yang dipakai oleh Philander Varian Massie karena sesuai dengan penelitian yang akan dilakukan.

\subsubsection{Keputusan Pembelian}

\subsubsection{Pengertian Keputusan}

\section{Pembelian}


Keputusan pembelian adalah proses pengintegrasian yang mengkombinasikan pengetahuan untuk mengevaluasi dua atau lebih perilaku alternatif dan memilih salah satu diantaranya (Peter dan Olson, 2000:162).

Pada umumnya, keputusan pembelian konsumen adalah membeli merek yang paling disukai (Kotler dan Amstrsong, 2012:181).

Keputusan membeli adalah tindakan menyeleksi beberapa pilihan alternatif dengan mengumpulkan informasi yang berhubungan dengan alternatif tersebut serta membuat pilihan yang sesuai dengan memilih salah satu alternatif yang ada. Keputusan membeli diukur dengan skala psikologis yang akan mengukur aspekaspek dari keputusan membeli (Engel dkk, 1995).

\subsubsection{Struktur Keputusan Pembelian}

Keputusan pembelian konsumen sebenarnya merupakan kumpulan dari sejumlah keputusan pembelian. Setiap keputusan pembelian tersebut memiliki strutur komponen yang berbeda, diantaranya (Oentoro, 2010:107):

a) Keputusan tentang jenis produk. Konsumen dapat memutuskan untuk membeli jenis produk tertentu seperti produk makanan atau produk elektronik.

b) Keputusan tentang bentuk produk. Keputusan pembelian ini berupa pemilihan bentuk produk menyangkut, ukuran, kualitas, desain produk dan sebagainya.

c) Keputusan tentang merek. Setiap merek memiliki perbedaan dan keunggulan tersendiri. Konsumen akan memutuskan membeli merek mana yang paling sesuai dengan keinginan dan kebutuhannya. d) Keputusan tentang penjual. Dalam mengambil keputusan pembelian konsumen akan menentukan dimana atau dari siapa dia akan membeli produk tersebut.

e) Keputusan tentang jumlah produk. Konsumen dapat mengambil keputusan tentang berapa banyak produk yang akan dibelinya.

f) Keputusan tentang waktu pembelian. Konsumen dapat mengambil keputusan tentang kapan mereka akan membeli suatu produk.

g) Keputusan tentang cara pembayaran. Ketika memutuskan untuk membeli suatu produk konsumen akan menentukan cara pembayaran produk yang dibeli, apakah secara tunai atau cicilan.

\subsubsection{Tahapan Keputusan \\ Pembelian}

Proses pencarian informasi. Tahap ini merupakan tahapan yang merangsang konsumen untuk mencari informasi lebih banyak mengenai suatu produk;

Evaluasi berbagai alternatif merek. Pada tahapan ini konsumen menggunakan informasi untuk mengevaluasi merek alternatif dalam menentukan peringkat produk untuk dipilih;

Pilihan atas merek produk untuk dibeli, dimana terjadi pembelian produk atas merek yang disukai berdasarkan peringkat dari tahapan 3, tetapi faktor situasi dan pendapat orang lain juga menentukan dalam tahapan ini;

Perilaku pasca pembelian. Kepuasan konsumen harus dipantau dari mulai pasca pembelian, tindakan pasca pembelian dan pemakaian produk pasca pembelian. 


\subsubsection{Indikator Keputusan} Pembelian

Menurut Philander Varian Massie $(2013,1477)$ Indikator keputusan pembelian yaitu: Kesadaran akan kebutuhan, pencarian informasi, evaluasi informasi, ketepatan dalam mengambil keputusan, dampak psikologis setelah melakukan pembelian.

Menurut M. Saleh Lubis, $(2013,150)$ Indicator keputusan pembelian yaitu: Kemantapan pada produk, Kebiasaan dalam pemilihan produk, Memberikan rekomendasi, Pemakaian ulang.

Menurut Yanina Sianturi, Erida, Ade Titi Nifita $(2012,130)$ Indicator keputusan pembelian yaitu: pengenalan masalah, pencarian informasi, evaluasi alternatif, keputusan pembelian dan perilaku sesudah pembelian.

Menurut Kottler $(2013,291)$ Indikator keputusan pembelian meliputi Pengenalan Kebutuhan, Pencarian Informasi, Evaluasi Alternatif, Keputusan Pembelian, Prilaku Pasca Pembelian

Dari beberapa pendapat diatas penulis memilih untuk mengambil Indikator yang dipakai Kottler, karena sesuai dengan objek penelitian yang akan diteliti.

\subsection{Kerangka Pemikiran}

Nilamsari merupakan perusahaan kecil yang bergerak di industri makanan yaitu pembuatan kue sebagai oleh-oleh para turis yang berkunjung ke Bandung. Dengan banyaknya usaha sejenis Nilamsari secara Umum akan meningkatkan pendapatan Khususnya Kota Bandung. Dan apabila usaha ini dapat berkembang menjadi lebih besar maka akan dapat menyerap banyak pegawai, dimana dapat mengurangi pengangguran pada umumnya sehingga perusahaan penting keberadaannya. Namun dengan banyaknya pesaing, maka apabila tidak dilakukan sebuah perubahan maka akan musnah, karena tidak dapat bertahan didalam persaingan bisnis. Maka dengan latar belakang tersebut diperlukan perbaikan pada produk tersebut agar dapat bertahan dalam persaingan bisnis salah satunya dengan memperbaiki kemasan dan Kesadaran merek akan produk sehingga konsumen melakukan keputusan pembelian akan produk tersebut.

Dengan kemasan produk ini dapat membuat produk ini lebih menarik sehingga masyarakat melakukan keputusan pembelian akan produk kue Nilamsari.hal ini seperti yang dijelaskan Kotler $(2013,122)$ bahwa kemasan dapat mempengaruhi minat konsumen dalam membeli sebuah produk. Dan kemasan sendiri memiliki beberapa indicator sebagai acuan dalam mengukur seberapa baik kemasan sebuah produk ( kottler 2013,21) yaitu melihat dari warna, ukuran , bentuk, logo dan Tulisan dengan menilai indicatorindikator tersebut maka dapat diketahui seberapa baik kemasan suatu produk.

Dengan melakukan penelitian mengenai kemasan produk ini dapat membuat produk ini memiliki ciri khas dan keunikan sehingga dapat memicu kesadaran merek masyarakat terhadap produk kue Nilamsari seperi yang diutarakan oleh Manilall Dhurup, Chengedzai Mafini, Tshepiso Dumasi $(2014,2)$ bahwa kemasan dapat membangun merek dalam benak konsumen, kesadaran merek sendiri sangat penting dalam menegasakan posisi suatu produk dalam benak konsumen dan dengan menggunakan indicator-indikator seperti (vilander 2013,1023) ingatan merek , hubungan symbol dengan merek dan ingatan merek maka dapat diketahui seberapa baik kesadaran merek seseorang pada sebuah produk

Menurut Kottler (2013:181). Konsumen biasanya memilih merek yang disukainya oleh sebab itu Dengan membangun Kesadaran Merek pada konsumen terhadap produk ini maka dapat mendorong masyarakat melakukan keputusan pembelian akan produk kue Nilamsari Menurut Kottler pula $(2013,291)$ 
Indikator keputusan pembelian meliputi Pengenalan Kebutuhan, Pencarian Informasi, Evaluasi Alternatif, Keputusan Pembelian, Prilaku Pasca Pembelian

\subsubsection{Keterkaitan Kemasan dengan Brand Awareness}

Menurut Duncan (2005) alam Astri dan Zalfiana $(2011,12)$ the packaging is the main instrument of communication with which companies can deliver brand messages. Accordingly, the packaging needs to be perceived as a highly important marketing communication tool in communicating the brand message, and has to be utilized to the fullest at the point of purchase in order to attract consumer attention. Kemasan adalah instrumen komunikasi dengan perusahaan dapat mengirim pesan merek. Kemasan perlu dibekali oleh alat komunikasi pemasaran dalam mengkomunkasi pesan Merek.

Manilall Dhurup, Chengedzai Mafini, Tshepiso Dumasi (2014,2) A study conducted by Bed (2008), which focused on existing practices of branding, packaging and labelling of new products in consumer product manufacturing units, reveals that the right packaging can help a brand to carve a unique position in the marketplace and in the minds of consumers. Artinya Sebuah studi yang dilakukan oleh Bed (2008), yang difokuskan pada praktekpraktek yang ada branding, kemasan dan pelabelan produk baru di unit manufaktur produk konsumen, mengungkapkan bahwa kemasan yang tepat dapat membantu merek untuk mengukir posisi yang unik di pasar dan di benak konsumen.

\subsubsection{Keterkaitan Kemasan dengan Keputusan Pembelian}

Menurut Shimp dalam Tjiptono (2000:32), point of purchase adalah elemen promosi seperti pajangan, poster, petunjuk atau tanda dan berbagai materi promosi yang lain termasuk kemasan yang baik didalam sebuah toko yang dirancang untuk mempengaruhi pikiran pelanggan pada momen pembelian.

Sigit (1992:34) menjelaskan bahwa dengan bungkus itu pihak konsumen menjadi tertarik, baik karena warna, gambar, tulisan, tanda-tanda, keterangan yang ada pada bungkusnya. Selanjutnya ia menambahkan "dengan pembungkus itu produsen atau pemasar dapat sekaligus menggunakannya sebagai alat advertensi, dengan memberikan tanda, simbol, tulisan, keterangan dan lain-lain yang bersifat membujuk, mempengaruhi atau memberikan informasi kepada calon pembeli supaya melaksanakan pembelian di tempat penjual atau di toko tertentu.

Menurut Kotler $(2013,122)$ : Perubahan pengemasan suatu produk biasanya juga dilakukan oleh produsen untuk dapat merebut minat konsumen terhadap pembelian barang. Produsen berusaha memberikan kesan yang baik pada kemasan produknya dan menciptakan model kemasan barang yang berbeda dengan produsen lain yang memproduksi produkproduk sejenis dalam pasar yang sama.

Menurut Dhar (2007) dalam Astri dan Zalfiana $(2011,12)$ packaging plays an important role at this meeting point (also known as the point of purchase), as this is the most important point of interaction between brands and consumers; it is at this stage that consumers decide which brands to purchase. Kemasan memegang peranan penting pada titik pertemuan ini (juga dikenal sebagai titik pembelian), karena ini adalah titik paling penting dari interaksi antara merek dan konsumen; itu pada tahap ini bahwa konsumen memutuskan untuk membeli merek.

\subsubsection{Keterkaitan Brand Awareness dengan Keputusan Pembelian}


Rossiter dan Percy (1987) dalam Emma Macdonald and Byron Sharp (2003) menggambarkan kesadaran merek (brand awareness) sebagai elemen terpenting di dalam proses komunikasi dan merupakan standar prosedur dalam setiap prosesnya. Tanpa adanya kesadaran merek, tidak ada efek komunikasi yang lain yang muncul. Bagi seorang konsumen yang membeli produk suatu merek, pertama-tama, mereka harus dibuat untuk mengenal merek tersebut. Sikap terhadap merek tidak dapat dibentuk, dan ketertarikan untuk membeli tidak akan timbul kecuali kesadaran merek sudah ada dalam benak mereka.

Menurut Kottler (2013:181). In general, the consumer purchase decision is to buy the most preferred brand. Pada umumnya, keputusan pembelian konsumen adalah membeli merek yang paling disukai.

Merek merupakan hal yang sangat penting, baik bagi produsen maupun konsumen. Dari sisi konsumen, merek akan mempermudah pembelian. Apabila tidak ada merek, maka konsumen harus melakukan evaluasi semua produk yang tidak memiliki merek setiap kali mereka melakukan pembelian. Selain itu, merek akan membantu meyakinkan konsumen bahwa mereka akan mendapatkan kualitas yang konsisten pada saat mereka membeli sebuah produk.

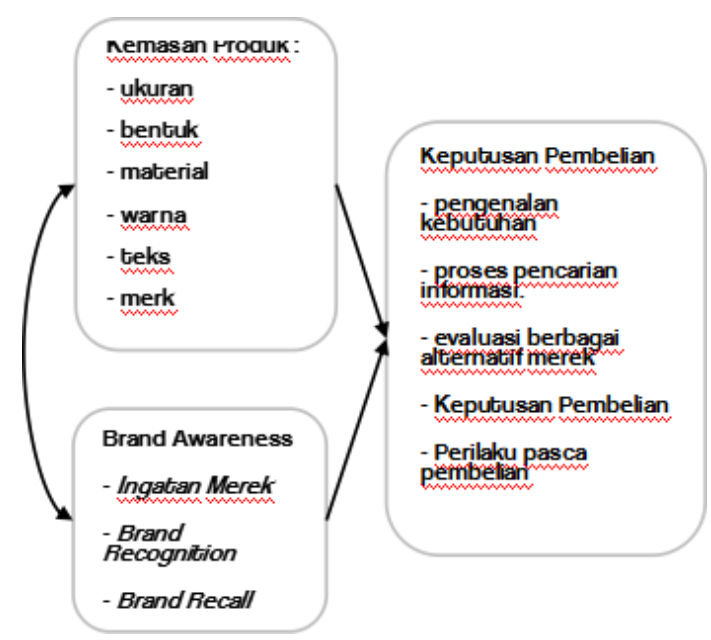

Gambar 1. Paradigma Penelitian

\subsection{Hipotesis}

\subsection{Hipotesis}

Hipotesis adalah dugaan sementara yang kebenarannya masih harus dilakukan pengujian. Hipotesis ini dimaksudkan untuk memberi arah bagi analisis penelitian (Marzuki, 2005).

Dengan Ini Penulis dapat menyimpulkan bahwa:

H1: Tanggapan Konsumen Mengenai Kemasan Produk Nilamsari baik, Tanggapan Konsumen Mengenai Kesadaran Merek Produk Nilamsari baik, Tanggapan Konsumen Mengenai Keputusan Produk Nilamsari baik.

H2: Terdapat hubungan kemasan produk dengan kesadaran Merek pada Produk kue Nilamsari.

H3: Terdapat Pengaruh Kemasan produk dan kesadaran merek terhadap Keputusan Pembelian pada Produk kue Nilamsari.di Bandung baik secara simultan maupun parsial

\section{Objek dan Metode Penelitian 3.1 Objek Penelitian}

Dalam penelitian ini Nilamsari memiliki 7 tempat penjualan yang tersebar di kota bandung Namun penulis membatasi peneltian ini namun dalam penelitian penulis hanya membatasi menjadi 2 tempat saja yaitu di daerah pasteur dan padalarang hal ini dikarenakan 2 tempat tersebut adalah titik teramai penjualan produk dari Nilamsari. Dan jumlah Populasi dari 2 titik tersebut adalah 800 hal ini diketahui dari Kepala bagian pemasaran yang selalu memasok sekitar 800 produk Nilamsari / bulan kepada titik tersebut adapun pembagian produk tersebut adalah 400 buah di daerah padalarang dan 400 buah di daerah pasteur.

\subsection{Metode Penelitian}


Metode deskriptif ini merupakan metode yang bertujuan untuk mengetahui sifat serta hubungan yang lebih mendalam antara dua variabel dengan cara mengamati aspek-aspek tertentu secara lebih spesifik untuk memperoleh data yang sesuai dengan masalah yang ada dengan tujuan penelitian, dimana data tersebut diolah, dianalisis, dan diproses lebih lanjut dengan dasar teoriteori yang telah dipelajari sehingga data tersebut dapat ditarik sebuah kesimpulan.

Penelitian ini dimaksudkan untuk menguji hipotesis dengan menggunakan perhitungan statistik. Penelitian ini digunakan untuk menguji pengaruh variabel $\mathrm{X}$ terhadap $\mathrm{Y}$ yang diteliti. Verifikatif berarti menguji teori dengan pengujian suatu hipotesis apakah diterima atau ditolak.

Dengan menggunakan metode penelitian akan diketahui hubungan yang signifikan antara variabel yang diteliti sehingga menghasilkan kesimpulan yang akan memperjelas gambaran mengenai objek yang diteliti.

Teknik yang digunakan dalam penelitian ini adalah teknik Nonprobability Sampling, Sampling Insidental dikarenakan tidak setiap konsumen dapat dijadikan sampel jadi hanya konsumen yang secara kebetulan membeli dan dikira cocok dan dapat dijadikan sumber data yang diberikan kuesioner,

Menurut Sugiyono, (2011:66) Nonprobability Sampling yaitu teknik pengambilan sampel yang tidak memberi peluang/kesempatan yang sama bagi setiap unsur (anggota) populasi untuk dipilih menjadi anggota sampel.

Menurut Sugiyono Sampling Insidental (2011 :67 )adalah tekik penentuan sampel berdasarkan kebetulan, yaitu siapa saja yang secara kebetulan/insidental bertemu dengan peneliti dapat digunakan sebagai sampel, bila dipandang orang yang kebetulan ditemui itu cocok sebagai sumber data (Sugiyono, 2011:67).
Metode penarikan sampel yang digunakan mengacu kepada pendekatan Slovin, pendekatan ini dinyatakan dengan rumus:

$$
n=\frac{N}{1+N e^{2}}
$$

$$
\begin{aligned}
& \text { Keterangan: } \\
& \mathrm{n}=\text { Jumlah sampel } \\
& \mathrm{N}=\text { Jumlah populasi } \\
& \mathrm{e}=\text { Batas kesalahan yang } \\
& \text { ditoleransi }(1 \%, 5 \%, 10 \%)
\end{aligned}
$$

Jika penelitian menggunakan metode deskriptif, maka minimal tingkat kesalahan dalam penentuan anggota sampel yang harus diambil adalah 10\% dari jumlah populasi yang diketahui. Dan semakin banyak sample yang dilibatkan maka semakin akurat pula hasil yang didapatkan oleh karena itu dalam penelitian ini penulis menaikan batas atas kesalahan yang ditoleransi menjadi $5 \%$ agar hasil menjadi lebih akurat.

Lalu berdasarkan rumus diatas, maka dapat diketahui sampel yang akan dipakai dalam penelitian ini yaitu:

$$
\begin{aligned}
& n=\frac{800}{1+800.0,05^{2}} \\
& n=\frac{800}{3} \\
& n=266.7=267
\end{aligned}
$$

Berdasarkan hasil perhitungan dengan batas kesalahan $5 \%$ jumlah sampel yang diambil adalah responden.

Untuk menentukan rincian sampel masing-masing cabang mengacu pendapat nazir $(1998 ; 365)$ dengan rumus.

$$
\boldsymbol{n} \mathbf{l}=\frac{N \mathbf{1}}{N} \boldsymbol{x n}
$$

Dimana :

$\mathrm{n} 1=$ Ukuran sampel yang harus diambil dari startum-i (suatu wilayah usaha) 
N1 = Ukuran Populasi stratum-i (suatu wilayah usaha)

$\mathrm{N}=$ Ukuran Populasi keseluruhan

$\mathrm{N}=$ Ukuran sampel keseluruhan

Tabel 3.4.

\begin{tabular}{|c|c|c|c|}
\hline $\begin{array}{l}\mathrm{N} \\
\mathrm{O}\end{array}$ & $\begin{array}{c}\mathrm{Ca} \\
\text { ban } \\
\mathrm{g}\end{array}$ & $\begin{array}{c}\text { Juml } \\
\text { ah } \\
\text { kons } \\
\text { umen }\end{array}$ & Sampel \\
\hline 1 & $\begin{array}{c}\text { Pas } \\
\text { teu } \\
\mathrm{r}\end{array}$ & 400 & $\pi 1=\frac{490}{817} \times 267=133,5=134$ \\
\hline 2 & $\begin{array}{l}\text { Pad } \\
\text { alar } \\
\text { ang }\end{array}$ & 400 & $\pi 1=\frac{490}{8 X 0} \times 267=133,5=134$ \\
\hline \multicolumn{3}{|c|}{ Jumlah } & 268 \\
\hline
\end{tabular}

Jumlah Sampel Cabang

Dari hasil tersebut penulis membulatkan sampel menjadi 270 agar mempermudah penulis dalam pengujian

Pengumpulan data dalam pnelitian ini dilakukan dengan menggunakan kuisioner, maka kesungguhan responden dalam menjawab pertanyaan-pertanyaan yang terdapat dalam kuisioner sangat penting. Keabsahan/kesalahan suatu hasil penelitian ditentukan oleh alat ukur/instrument yang digunakan. Sugiyono (2010, p.146) instrumen penelitian adalah suatu alat yang digunakan untuk mengukur fenomena alam yang diamati. Untuk menguji tingkat kualitas data terdapat dua konsep yaitu uji validitas dan uji reabilitas.

Uji validitas dan reabilitas dalam suatu penelitian sangat penting karena mencakup mutu seluruh proses pengambilan data sejak konsep disiapkan sampai data siap untuk dianalisis. Dengan adanya uji validitas dan reabilitas maka kita dapat memberikan kesimpulan dan alasanalasan terhadap hubungan antar variabel.
4. Hasil Penelitian dan Pembahasan

1.1 Karakteristik Responden

1.1.1 Profil Responden Berdasarkan Jenis Kelamin

Berikut merupakan penjelasan karakteristik responden berdasarkan penelitian data-data pribadi responden. Data-data pribadi responden tersebut terdiri dari jenis kelamin, usia, pekerjaan, pengeluaran perbulan, lamanya berlanggan dan frekuensi bulanan.

Peneliti mendapatkan data responden sebanyak 300 responden, dari 300 kuesioner yang diisi oleh konsumen Nilamsari.

Berikut adalah hasil analisis dari karakteristik responden berdasarkan jenis kelamin, usia, tingkat pendidikan, pekerjaan, dan tingkat pengeluaran rata-rata per bulan, yang diperoleh berdasarkan jawaban yang diberikan oleh responden atas pertanyaan dalam kuesioner.

\subsubsection{Profil Responden Berdasarkan Jenis Kelamin}

\subsubsection{Jenis Kelamin Responden}

\begin{tabular}{|l|l|l|}
\hline $\begin{array}{l}\text { Jenis } \\
\text { Kelamin }\end{array}$ & Jumlah & \multicolumn{2}{|c|}{ Persentase\% } \\
\hline Pria & 52 & \\
\hline Wanita & 215 & 80 \\
\hline Jumlah & 267 & 100 \\
\hline
\end{tabular}

Sumber: Hasil olah data kuesioner, 2014

Pada diatas dapat dilihat bahwa pembeli produk nilamsari 20\% laki-laki dan $80 \%$ perempuan, berarti mayoritas pembeli produk nilamsari adalah wanita . ini sesuai karena wanita menyukai kue dan membuat kue. 


\subsubsection{Profil Responden Berdasarkan Tingkat Usia}

\section{Tingkat Usia Responden}

\begin{tabular}{|l|c|c|}
\hline Tingkat Usia & Jumlah & $\begin{array}{l}\text { Persentase } \\
\%\end{array}$ \\
\hline $\mathbf{2 0}$ & 16 & 5.99 \\
\hline $\mathbf{2 0}-\mathbf{2 5}$ & 48 & 17.97 \\
\hline $\mathbf{2 6}-\mathbf{3 5}$ & 102 & 38.20 \\
\hline $\mathbf{3 6} \mathbf{- 4 5}$ & 95 & 35.58 \\
\hline $\mathbf{> 4 5}$ & 6 & 2.24 \\
\hline Jumlah & 267 & 100 \\
\hline
\end{tabular}

Sumber: Hasil olah data kuesioner, 2014

Berdasarkan tabel diatas dapat disimpulkan bahwa mayoritas responden dalam penelitian ini bahwa responden dibawah 20 tahun sebanyak 5\%, responden di usia Antara 20-25 tahun 17\%, responden diusia 26-35 tahun sekitar 38\%, responden berumur 36-45 sekitar 35\%, dan responden diatas 45 tahun sekitar 2\%. Jumlah responden didominasi oleh wanita berumur 26-45 tahun dengan kata lain mayoritas konsumen nilamsari adalah wanita yang sudah cukup dewasa. Ini dikarenakan karena wanita dewasa sudah dapat menentukan barang yang mau dibeli dan memiliki uang untuk membelinya.

\subsubsection{Profil Responden Berdasarkan Tingkat Pendidikan}

\section{Tingkat Pendidikan Responden}

\begin{tabular}{|l|l|l|}
\hline $\begin{array}{l}\text { Tingkat } \\
\text { Pendidikan }\end{array}$ & Jumlah & $\begin{array}{l}\text { Persentase } \\
\%\end{array}$ \\
\hline SMP & 5 & 1.87 \\
\hline SMA & 136 & 50.9 \\
\hline S1/D3 & 117 & 43.82 \\
\hline S2/S3 & 7 & 2.62 \\
\hline Lain-lain & 2 & 0.74 \\
\hline
\end{tabular}

\begin{tabular}{|l|l|l|}
\hline Jumlah & 267 & 100
\end{tabular}

Sumber: Hasil olah data kuesioner, 2014

Berdasarkan tabel diatas dapat diketahui bahwa mayoritas responden memiliki tingkat pendidikan SMP sekitar $2 \%$ responden, SMA $50 \%$ responden, S1/D3 43\% responden, S2/S3 2\% responden dan lain -lain sekitar 2\%. Dari data ini dapat dilihat bahwa pembeli produk Nilamsari mayoritas adalah Lulusan SMA dan S1/D3.ini sesuai dengan pekerjaan dari konsumen dimana mayoritas pembeli adalah pegawai negeri dan swasta dimana untuk mendapatkan pekerjaan tersebut konsumen harus memiliki pendidikan minimal SMA..

\subsubsection{Profil Responden Berdasarkan Tingkat Pekerjaan}

\section{Tingkat Pekerjaan Responden}

\begin{tabular}{|l|l|l|}
\hline $\begin{array}{l}\text { Tingkat } \\
\text { Pekerjaan }\end{array}$ & $\begin{array}{l}\text { Jumla } \\
\text { h }\end{array}$ & $\begin{array}{l}\text { Persentas } \\
\text { e \% }\end{array}$ \\
\hline $\begin{array}{l}\text { Pelajar/ } \\
\text { Mahasiswa }\end{array}$ & 12 & 4.49 \\
\hline Pegawai Negeri & 96 & 35.95 \\
\hline Karyawan Swasta & 71 & 26.59 \\
\hline Wiraswasta & 23 & 8.61 \\
\hline Lain-lain & 65 & 24.34 \\
\hline Jumlah & 267 & 100 \\
\hline
\end{tabular}

Sumber: Hasil olah data kuesioner, 2014

Berdasarkan tabel diatas dapat diketahui bahwa mayoritas responden memiliki yang mengikuti survey ini adalah mahasiswa sebanyak 4\%, Pegawai negeri $35 \%$, Karyawan swasta $27 \%$, wiraswasta $23 \%$, dan lain-lain 24\% mayoritas pembeli Nilamsari adalah pegawai negeri dikarenakan pegawai negeri memiliki cukup uang untuk berwisata ke bandung dan membeli oleh-oleh termasuk kue Nilamsari. 


\subsubsection{Profil Responden Berdasarkan Tingkat Pengeluaran Rata-rata/ Bulan}

\section{Tingkat Pengeluaran Rata- rata (per Bulan) Responden}

\begin{tabular}{|l|l|l|}
\hline $\begin{array}{l}\text { Tingkat Pengeluaran Rata- } \\
\text { rata /Bulan }\end{array}$ & Jumlah & Persentase \% \\
\hline < Rp 2.500.000,- & 0 & 0 \\
\hline $\begin{array}{l}\text { Rp 2.500.000,- Rp } \\
\mathbf{5 . 0 0 0 . 0 0 0 , -}\end{array}$ & 97 & 36.32 \\
\hline $\begin{array}{l}\text { Rp 5.000.000 - Rp } \\
\text { 7.500.000,- }\end{array}$ & 156 & 58.42 \\
\hline > Rp 7.500.000,- & 14 & 5.24 \\
\hline Jumlah & 267 & 100 \\
\hline
\end{tabular}

Sumber: Hasil olah data kuesioner, 2014

Berdasarkan tabel diatas dapat diketahui bahwa responden yang memiliki tingkat pengeluaran rata-rata per bulan sebesar <Rp 2.500.000,- adalah sebanyak $0 \%$. Lalu responden dengan pengeluaran rata-rata per bulan $\mathrm{Rp} 2.500 .000$ - $\mathrm{Rp}$ $5.000 .000,-$, adalah sebanyak $36 \%$. Sedangkan sebanyak responden memiliki pengeluaran rata-rata per bulan sebesar $\mathrm{Rp}$ 5.000.000 - Rp 7.500.000,-. Sebanyak 58\% Dan sisanya sebanyak $6 \%$ memiliki pengeluaran rata-rata per bulan sebesar lebih dari 7.500.000 rupiah. Penjual Nilamsari mayoritas berpenghasilan $\mathrm{Rp}$ 5.000.000 - Rp 7.500.000,-. Ini dikarenakan Pembeli Nilamsari mayoritas adalah tulis local yang berdomisili di Jakarta sehingga apabila konsumen tidak memiliki pendapatan sebesar angka tersebut sulit untuk konsumen dating ke bandung dan membeli oleh-oleh dikarenakan keterbatasan dana sehingga mayoritas konsumen dengan pendapatan $\mathrm{Rp}$ 5.000.000 - Rp 7.500.000,-. Yang banyak membeli produk Nilamsari.

\subsection{Analisis Deskriptif \\ 4.2.1 Penerapan Kemasan $\left(\mathrm{X}_{1}\right)$}

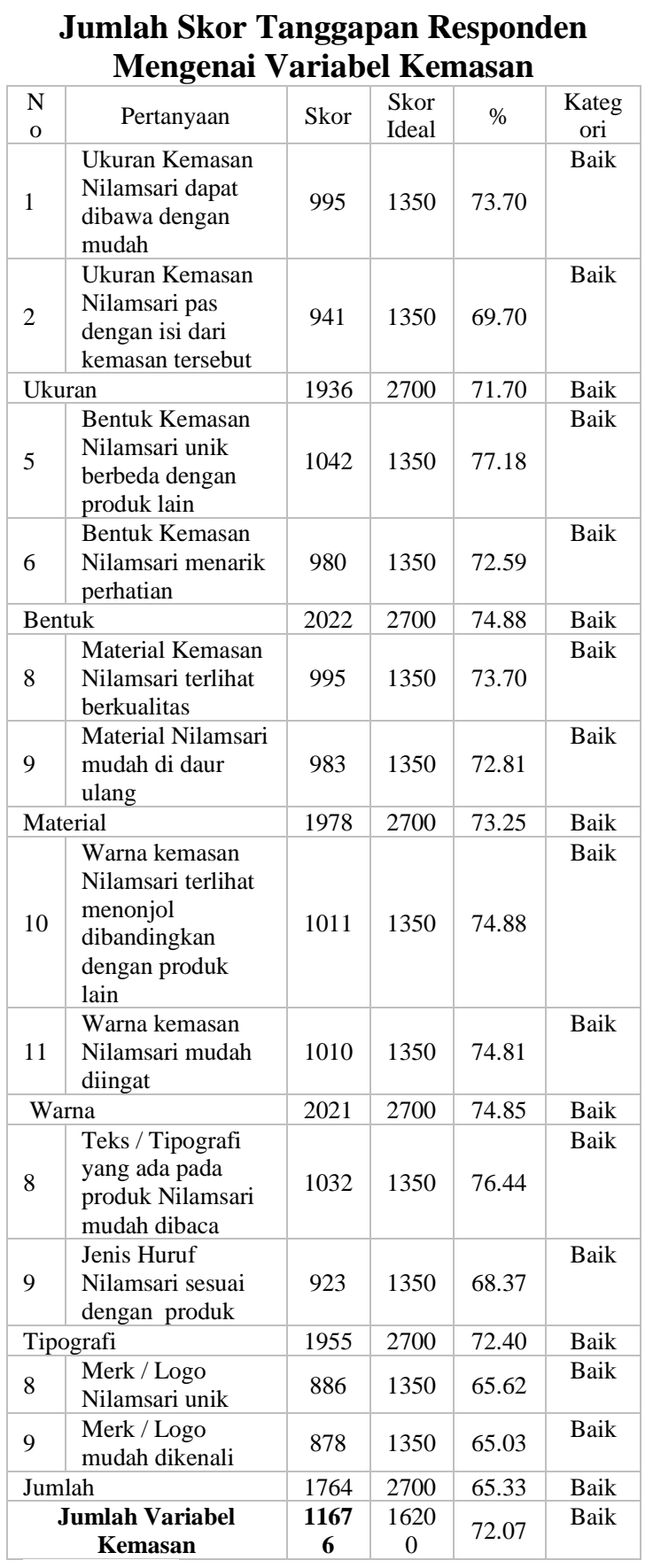

72.01

Sumber: Hasil olah data primer,

2014

Berdasarkan tabel di atas, persentase skor total untuk Variabel Kemasan adalah sebesar $72 \%$ yang terletak antara rentang $60,00 \%$ s/d 80,00\%. Dengan demikian, Variabel Kemasan berada pada tingkat baik. 
Pentingnya kemasan ini dungkapkan oleh Silayoi\& Speece 2004 dalam Manilall Dhurup, Chengedzai Mafini dan Tshepiso Dumasi (2014,2 ) Packaging appears to be one of the important factors in purchase decisions that are made at the point of sale where it becomes an essential part of the selling process (Silayoi\& Speece 2004) artinya Kemasan tampaknya menjadi salah satu faktor penting dalam keputusan pembelian yang dibuat pada titik penjualan di mana menjadi bagian penting dari proses penjualan.

Berdasarkan hasil rekapitulasi dari indikator kemasan ini, bisa dibilang bahwa kemasan Nilamsari ini berada di level baik, sehingga seharusnya nilamsari meningkatkan kualitas kemasan produknya karena dengan bertambahnya pesaing maka kemasan pun harus diperbaiki agar produk dapat lebih menarik perhatian konsumen sehingga Produk Nilamsari dapat bertahan di Pasar.

Adapun skor tertinggi ada di Indikator Bentuk (74,88\%)dimana Bentuk pada kemasan Nilamsari ini sudah baik dan skor terendah ada pada logo $(65,03 \%)$ sehingga diperlukan perbaikan, namun secara ratarata variable kemasan ada di kriteria baik ,namun perlu diperhatikan dengan banyaknya pesaing yang masuk maka tidak ada salahnya kemasan nilamsari yang sudah baik ini ditingkatkan guna menaikan daya saing dan dapat menarik calon konsumen yang belum mencoba dikarenakan hasil pengukuran ini hanya terbatas pada responden yang sudah mencoba nilamsari.

\subsubsection{Kesadaran Merek $\left(\mathrm{X}_{2}\right)$}

Jumlah Skor Tanggapan Responden Mengenai Variabel Kesadaran Merek

\begin{tabular}{|l|l|l|l|l|l|}
\hline $\begin{array}{l}\text { N } \\
\text { o }\end{array}$ & Pertanyaan & Skor & $\begin{array}{c}\text { Skor } \\
\text { Ideal }\end{array}$ & $\%$ & Kategori \\
\hline
\end{tabular}

\begin{tabular}{|c|c|c|c|c|c|}
\hline 1 & $\begin{array}{l}\text { Nilamsari adalah } \\
\text { Merk yang } \\
\text { pertama terlintas } \\
\text { dalam pikiran saya }\end{array}$ & 882 & 1350 & 65.33 & Baik \\
\hline 2 & $\begin{array}{l}\text { Merk Nilamsari } \\
\text { mudah dilafalkan }\end{array}$ & 988 & 1350 & 73.19 & Baik \\
\hline 3 & $\begin{array}{l}\text { Nilamsari adalah } \\
\text { Merk yang } \\
\text { pertama terlintas } \\
\text { dalam pikiran saya }\end{array}$ & 968 & 1350 & 71.70 & Baik \\
\hline \multicolumn{2}{|c|}{ Ingatan Merek } & 2838 & 4050 & 70.07 & Baik \\
\hline 4 & $\begin{array}{l}\text { Nilamsari } \\
\text { merupakan merk } \\
\text { yang terkenal }\end{array}$ & 1006 & 1350 & 74.52 & Baik \\
\hline 5 & $\begin{array}{l}\text { Warna dominan } \\
\text { pada produk } \\
\text { Nilamsari adalah } \\
\text { kuning }\end{array}$ & 905 & 1350 & 67.04 & Baik \\
\hline \multicolumn{2}{|c|}{ Pengenalan Merek } & 1911 & 2700 & 70.78 & Baik \\
\hline 6 & $\begin{array}{l}\text { Logo pada Merk } \\
\text { Nilamsari mudah } \\
\text { dikenali }\end{array}$ & 878 & 1350 & 65.04 & Baik \\
\hline 7 & $\begin{array}{l}\text { Logo pada merk } \\
\text { Nilamsari terlihat } \\
\text { serasi / sesuai }\end{array}$ & 932 & 1350 & 69.04 & Baik \\
\hline \multicolumn{2}{|c|}{ Simbol dengan Merek } & 1810 & 2700 & 67.04 & Baik \\
\hline \multicolumn{2}{|r|}{$\begin{array}{c}\text { Jumlah Variabel } \\
\text { Kesadaran Merek }\end{array}$} & 6559 & 9450 & 69.41 & Baik \\
\hline
\end{tabular}

Sumber: Hasil olah data primer, 2014

Berdasarkan tabel di atas, persentase skor total untuk Variabel Kesadaran Merek adalah sebesar $69.41 \%$ yang terletak antara rentang $60,00 \% \mathrm{~s} / \mathrm{d} \quad 80,00 \%$. Dengan demikian, Kesadaran Merek berada pada tingkat baik.pentingnya kesadaran merek ini diungkapkan oleh (Durianto, 2004:7) Meningkatkan kesadaran adalah suatu mekanisme untuk memperluas pasar merek. Kesadaran merek juga mempengaruhi persepsi dan tingkah laku. Kesadaran merek merupakan key of brand asset atau kunci pembuka untuk masuk ke elemen lainnya. Jadi, jika kesadaran itu sangat rendah maka hampir dipastikan bahwa ekuitas mereknya juga rendah. (Durianto, 2004:7)

Berdasarkan hasil rekapitulasi dari Variabel Kesadaran Merek ini, bisa dibilang bahwa kesadaran konsumen terhadap produk Nilamsari ini berada di level baik. Namun dengan bertambahnya pesaing di pasar seharusnya nilamsari kesadaran merek konsumen terhadap produknya karena dengan meningkatkan kesadaran merek konsumen terhadap merek nilamsari 
dapat membuat konsumen memutuskan membeli produk ini.

Adapun skor tertinggi ada di Indikator Ingatan Merek dimana Ingatan Merek $(70,07 \%)$ pada produk Nilamsari ini sudah baik dan skor terendah ada pada hubungan Simbol dengan Merek (67,04\%)sehingga diperlukan perbaikan, namun secara ratarata variable kesadaran merek ada di kriteria baik ,namun perlu diperhatikan dengan banyaknya pesaing yang masuk maka tidak ada salahnya kesadaran merek nilamsari yang sudah baik ini ditingkatkan guna menaikan daya saing dan dapat menarik calon konsumen yang belum mencoba dikarenakan hasil pengukuran ini hanya terbatas pada responden yang sudah mencoba nilamsari.

\subsubsection{Keputusan Pembelian (Y)}

\section{Jumlah Skor Tanggapan Responden}

\section{Mengenai Variabel Keputusan}

\section{Pembelian}

\begin{tabular}{|c|c|c|c|c|c|}
\hline $\begin{array}{l}\mathrm{N} \\
\mathrm{o}\end{array}$ & Pertanyaan & Skor & $\begin{array}{l}\text { Skor } \\
\text { Ideal }\end{array}$ & $\%$ & $\begin{array}{c}\text { Kateg } \\
\text { ori }\end{array}$ \\
\hline 1 & $\begin{array}{l}\text { Tingkat Kebutuhan } \\
\text { saya terhadap } \\
\text { produk Nilamsari } \\
\text { tinggi }\end{array}$ & 917 & 1350 & 67.93 & Baik \\
\hline 2 & $\begin{array}{l}\text { Saya selalu } \\
\text { menginginkan } \\
\text { produk Nilamsari }\end{array}$ & 986 & 1350 & 73.04 & Baik \\
\hline \multicolumn{2}{|c|}{ pengenalan kebutuhan } & 1903 & 2700 & 70.48 & Baik \\
\hline 3 & $\begin{array}{l}\text { Saya sering mencari } \\
\text { tahu informasi } \\
\text { mengenai Nilamsari }\end{array}$ & 986 & 1350 & 73.04 & Baik \\
\hline 4 & $\begin{array}{l}\text { Saya memiliki rasa } \\
\text { penasaran yang } \\
\text { tinggi terhadap } \\
\text { produk nilamsari }\end{array}$ & 1018 & 1350 & 75.41 & Baik \\
\hline \multicolumn{2}{|c|}{ pencarian alternatif } & 2004 & 2700 & 74.22 & Baik \\
\hline 5 & $\begin{array}{l}\text { Saya memilih } \\
\text { Nilamsari sebagai } \\
\text { Alternatif utama } \\
\text { kue dibandingkan } \\
\text { dengan produk lain } \\
\text { sejenis }\end{array}$ & 902 & 1350 & 66.81 & Baik \\
\hline 6 & $\begin{array}{l}\text { Produk Nilamsari } \\
\text { lebih bagus } \\
\text { dibandingkan } \\
\text { dengan produk } \\
\text { lainnya }\end{array}$ & 892 & 1350 & 66.07 & Baik \\
\hline
\end{tabular}

\begin{tabular}{|c|c|c|c|c|c|}
\hline \multicolumn{2}{|c|}{ evaluasi } & 1794 & 2700 & 66.44 & Baik \\
\hline 7 & $\begin{array}{l}\text { Saya yakin dengan } \\
\text { keputusan saya } \\
\text { membeli produk } \\
\text { kue Nilamsari }\end{array}$ & 983 & 1350 & 72.81 & Baik \\
\hline 8 & $\begin{array}{l}\text { Nilamsari } \\
\text { merupakan pilihan } \\
\text { yang tepat bagi saya }\end{array}$ & 976 & 1350 & 72.30 & Baik \\
\hline \multicolumn{2}{|c|}{ keputusan pembelian } & 1959 & 2700 & 72.56 & Baik \\
\hline 9 & $\begin{array}{l}\text { Saya puas membeli } \\
\text { Nilamsari }\end{array}$ & 1003 & 1350 & 74.30 & Baik \\
\hline 10 & $\begin{array}{l}\text { Saya akan membeli } \\
\text { lagi Nilamsari }\end{array}$ & 930 & 1350 & 68.89 & Baik \\
\hline \multicolumn{2}{|c|}{$\begin{array}{l}\text { Jumlah prilaku pasca } \\
\text { pembelian }\end{array}$} & 1933 & 2700 & 71.59 & Baik \\
\hline \multicolumn{2}{|c|}{$\begin{array}{c}\text { Jumlah Variabel } \\
\text { Keputusan Pembelian }\end{array}$} & 9593 & $\begin{array}{c}1350 \\
0\end{array}$ & 71.06 & Baik \\
\hline
\end{tabular}

Sumber: Hasil olah data primer, 2014

Berdasarkan tabel di atas, persentase skor total untuk Variabel keputusan pembelian adalah sebesar $71,06 \%$ yang terletak antara rentang 60,00\% s/d 80,00\%. Dengan demikian, Keputusan Pembelian berada pada tingkat baik ini diungkapkan oleh (Sunarto, 2004: 16).Proses pembelian yang spesifik terdiri dari urutan kejadian berikut: pengenalan masalah kebutuhan, pencarian informasi, evaluasi alternatif, keputusan pembelian dan perilaku setelah pembelian, sehingga jelas bahwa pemasar perlu fokus pada seluruh proses pengambilan keputusan

Berdasarkan hasil rekapitulasi dari variabel keputusan pembelian ini, bisa dibilang bahwa kesadaran Nilamsari ini berada di level baik. Namun dengan bertambahnya pesaing di pasar seharusnya nilamsari dapat, meningkatkan variablevariabel yang menaikan keputusan pembelian konsumen terhadap produknya.

Adapun skor tertinggi ada di Indikator pencarian informasi (74,22\%)dimana pencarian informasi pada produk Nilamsari ini sudah baik dan skor terendah ada pada pencarian alternatif dengan Merek $(66,44 \%)$ sehingga diperlukan perbaikan, namun secara rata- rata variable keputusan pembelian ada di kriteria baik ,namun perlu diperhatikan dengan banyaknya pesaing yang masuk maka tidak ada salahnya keputusan pembelian nilamsari yang sudah baik ini ditingkatkan guna menaikan daya 
saing dan dapat menarik calon konsumen yang belum mencoba dikarenakan hasil pengukuran ini hanya terbatas pada responden yang sudah mencoba nilamsari.

\subsection{Analisis Verifikatif}

\subsubsection{Analisis Path Diagram (Analisis Diagram Jalur)}

Path Diagram dibawah ini merupakan hasil analisis data dari output path diagram menggunakan software LISREL 8.72 yang menggambarkan pengaruh variabel eksogen terhadap variabel endogen. Variabel eksogen terdiri dari variabel X1 (kemasan), X2 (kesadaran Merek) serta variabel eksogen adalah Y (Kputusan Pembelian). Dibawah ini akan dijelaskan secara rinci path analysis dari pengaruh variabel eksogen terhadap variabel endogen:

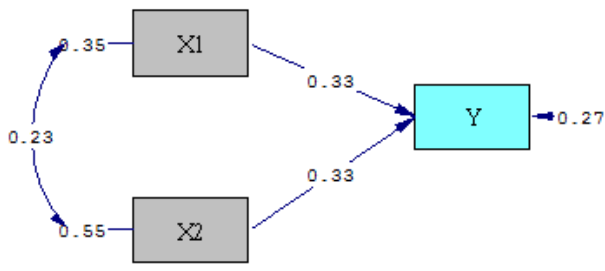

Path Diagram Variabel Kemasan, Kesadaran Merek, dan Keputusan pembelian

Sumber: Lisrel 8.72

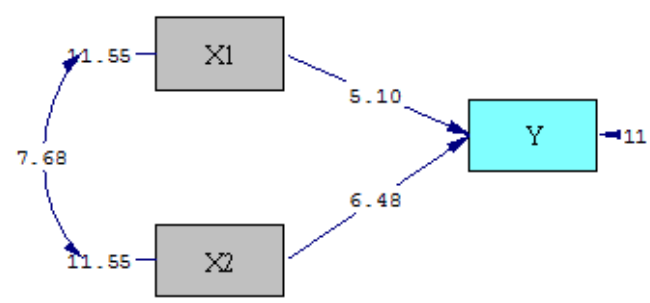

Structural Model T-values

Sumber: Lisrel 8.72

Berdasarkan path analysis pada ketiga gambar diatas maka diperoleh persamaan struktural model sebagai berikut:

$\mathbf{Y}=\mathbf{0 . 3 3} * \mathbf{X} 1+\mathbf{0 . 3 3} * \mathbf{X} 2 \mathrm{R}^{2}=0.35$
Ini menjelaskan bahwa $\mathrm{Y}$ adalah total pengaruh dari $\mathrm{X} 1$ dan $\mathrm{X} 2$ dikalikan besarnya pengaruh dimana dalam gambar dapat dilihat bahwa pengaruh $\mathrm{X} 1 \mathrm{ke} \mathrm{Y}$ adalah 0,33 dan bahwa pengaruh $\mathrm{X} 2$ ke $\mathrm{Y}$ adalah 0,33 sehingga menghasilkan total pengaruh $(\mathrm{R} 2)$ sebesar 0,35

a. Hubungan Kemasan Terhadap Kesadaran Merek Produk Nilamsari

Berdasarkan hasil yang diperoleh dari path diagram terdapat hubungan positif Antara kemasan terhadap kesadaran merek yaitu sebanyak 0,23 . Hal tersebut berarti apabila variabel kemasan naik sebesar satu satuan maka variabel Kesadaran Merek pun akan naik sebesar 0,23

\section{b. Pengaruh Kemasan Terhadap} Keputusan Pembelian Nilamsari

Berdasarkan hasil yang diperoleh dari path diagram pengaruh Kemasan terhadap keputusan pembelian sebesar 0.33. Hal tersebut berarti apabila variabel kemasan naik sebesar satu satuan maka variabel keputusan pembelian akan naik sebesar 0,33

\section{c. Pengaruh Kesadaran Merk Terhadap Keputusan Pembelian Nilamsari}

Berdasarkan hasil yang diperoleh dari path diagram pengaruh Kesadaran Merk terhadap keputusan pembelian sebesar 0,33. Hal tersebut berarti apabila variabel Kesadaran Merk naik sebesar satu satuan maka variabel keputusan pembelian akan naik sebesar 0,33 .

d. Pengaruh Kemasan dan Kesadaran Merk Terhadap Keputusan Pembelian Nilamsari

Berdasarkan hasil yang diperoleh dari path diagram pengaruh kemasan dan kesadaran merek terhadap keputusan pembelian sebesar 0,35 . Hal tersebut berarti apabila variabel tempat naik sebesar satu satuan maka variabel kepuasan pelanggan akan naik sebesar 0,35.lalu $0,35 \times 100 \%=$ $35 \%$ sehingga variable sisanya yaitu $65 \%$ 
diterangkan oleh variable diluar model penelitian

\subsubsection{Analisis Pengujian Hipotesis}

\subsubsection{Pengujian Hipotesis Secara Simultan}

Pengujian secara simultan digunakan untuk mengetahui pengaruh seluruh variabel eksogen terhadap variabel endogen secara bersama-sama. Dibawah ini merupakan perhitungan nilai $\mathrm{F}$.

$$
\begin{aligned}
& F=\frac{(n-k-1) x R^{2}{ }_{n I_{1}}}{h\left(1-R 2_{n y}\right)} \\
& F=\frac{(270-2-1) \times 0,35}{2 x(1-0,35)}=30,37
\end{aligned}
$$

Dari perhitungan tersebut diatas, diperoleh nilai $\mathrm{F}$ hitung sebesar 30,37 sedangkan nilai F-tabel sebesar 3,030 dengan taraf signifikansi sebesar 0,05. Dikarenakan nilai $\mathrm{F}$ hitung lebih besar dari F- tabel maka disimpukan terdapat pengaruh yang signifikan antara X1 (Kemasan), X2 (Kesadaran Merk ) terhadap Y (Keputusan Pembelian).

\begin{tabular}{|l|l|l|l|}
\hline Variabel & $\mathbf{F}_{\text {hitung }}$ & $\mathbf{F}_{\text {tabel }}$ & Keterangan \\
\hline $\begin{array}{l}\text { Kemasan dan } \\
\text { Kesadaran merek }\end{array}$ & 30,37 & 3.030 & Signifikan \\
\hline
\end{tabular}

Hasil Pengujian Hipotesa dengan Uji F

Sumber: Hasil olah data Penelitian, 2014

\subsubsection{Pengujian Hipotesis Secara Parsial}

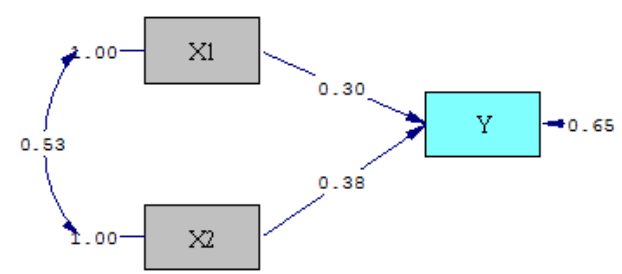

\section{Structural Model Standarized Solutiom}

Sumber: Lisrel 8.72

Uji hipotesis secara parsial digunakan untuk mengetahui tingkat signifikansi pengaruh masing-masing variable eksogen terhadap variabel endogen dengan melihat nilai $\mathrm{t}$ pada path diagram. Jika t-hitung lebih besar dari t-tabel maka maka Hi diterima.

a. Uji hipotesis variabel Kemasan terhadap keputusan Pembelian

Koefisien jalur kemasan terhadap keputusan pembelian adalah sebesar 0,30 dengan nilai t-hitung sebesar 5,10. Nilai t-tabel dengan signifikansi $\alpha 0,05$ adalah sebesar 1,97, sehingga $\mathrm{H} 1$ diterima yang berarti bahwa X1 Kemasan berpengaruh signifikan terhadap keputusan pembelian.

b. Uji hipotesis variabel Kesadaran Merk terhadap keputusan Pembelian

Koefisien jalur harga terhadap kepuasan pelanggan adalah sebesar 0,38 dengan nilai t-hitung sebesar 6,48 . Nilai t-tabel dengan signifikansi $\alpha 0,05$ adalah sebesar 1,97, sehingga $\mathrm{H} 1$ diterima yang berarti bahwa X2 kesadaran Merk berpengaruh signifikan terhadap keputusan pembelian

\section{Hasil Pengujian Hipotesa dengan Uji T}

\begin{tabular}{|l|l|l|l|l|l|}
\hline $\mathbf{N}$ & Hipotesis & $\begin{array}{l}\text { Koefi } \\
\text { sien } \\
\text { Jalur }\end{array}$ & $\begin{array}{l}\mathbf{T} \\
\text { hitung }\end{array}$ & $\mathbf{T}_{\text {tabel }}$ & Hasil \\
\hline
\end{tabular}




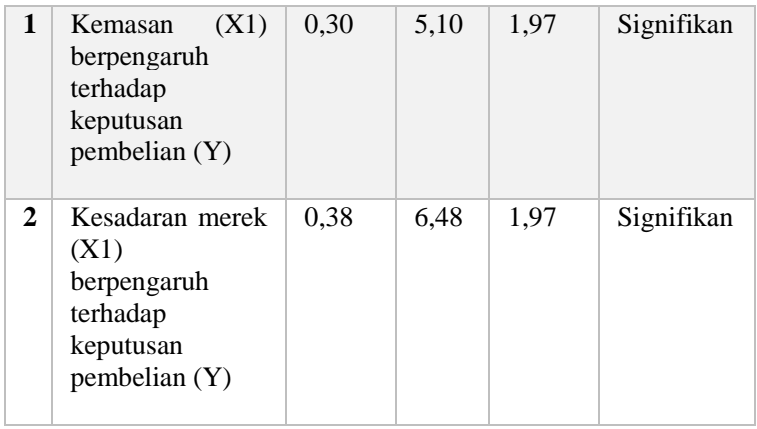

Sumber: Hasil olah data Penelitian, 2014

\subsubsection{Besar Pengaruh Kemasan , Kesadaran Merek terhadap Keputusan}

Berdasarkan hasil pengujian hipotesis secara parsial maupun simultan bahwa semua hipotesa menyatakan semuanya dapat diterima, sebab berdasarkan pengujian koefisien jalur dari kemasan ke keputusan pembelian dan kesadaran merek ke keputusan pembelian secara statistik bermakna. Hasil ini memberikan indikasi bahwa variabel kemasan dan kesadaran merek berpengaruh terhadap keputusan pembelian.

1. Pengaruh Kemasan terdahap Keputusan pembelian

Setelah pengujian koefisien jalur dari variabel Kemasan terdahap Keputusan pembelian secara statistik bermakna selanjutnya dapat diketahui besarnya pengaruh langsung dan tidak langsung dari Kemasan terdahap Keputusan pembelian

- Pengaruh langsung X1 terhadap Y

$\mathrm{P}_{\mathrm{YX} 1 \mathrm{X}} \mathrm{P}_{\mathrm{YX} 1}=0,30 \times 0,30=0,09=9,00 \%$

Dari hasil penghitungan diatas diketahui besarnya pengaruh langsung dari Kemasan terdahap Keputusan pembelian sebesar $9 \%$

- Pengaruh tidak langsung X1 terhadap Y melalui X2

$\mathrm{P}_{\mathrm{YX} 1 \mathrm{Xr}} \mathrm{r}_{\mathrm{X} \times 2} \mathrm{X} \mathrm{P}_{\mathrm{YX} 2}=0,30 \quad \mathrm{x} \quad 0,53 \quad \mathrm{x} \quad 0,30$ $=0,0477=4,77 \%$

Dari hasil penghitungan diatas diketahui besarnya pengaruh tidak langsung dari Kemasan melalui kesadaran merek terdahap Keputusan pembelian sebesar $4,77 \%$

Sehingga Total pengaruh ( Pengaruh langsung dan tidak langsung) variabel Kemasan terdahap Keputusan pembelian sebesar $9,00 \%+4,77 \%=13,77 \%$

2. Pengaruh Kesadaran Merek terhadap Keputusan Pembelian

Setelah pengujian koefisien jalur dari variabel Kesadaran merek terdahap Keputusan pembelian secara statistik bermakna selanjutnya dapat diketahui besarnya pengaruh langsung dan tidak langsung dari Kesadaranb meren terdahap Keputusan pembelian

- Pengaruh langsung X2 terhadap Y $\mathrm{P}_{\mathrm{YX} 1 \mathrm{X}} \mathrm{P}_{\mathrm{YX} 1}=0,38 \times 0,38=0,1444=14,44 \%$ Dari hasil penghitungan diatas diketahui besarnya pengaruh langsung dari Kesadaran Merek terdahap Keputusan pembelian sebesar $10,89 \%$

- Pengaruh tidak langsung X2 terhadap Y melalui X1

$\mathrm{P}_{\mathrm{YX} 1 \times \mathrm{Xr}_{\mathrm{X} 1 \times 2} \mathrm{X} \mathrm{P}_{\mathrm{YX} 2}=0,38 \mathrm{x}} \quad 0,53 \quad \mathrm{x} \quad 0,38$ $=0,07653=7,56 \%$

Dari hasil penghitungan diatas diketahui besarnya pengaruh tidak langsung dari Kemasan melalui kesadaran merek terdahap Keputusan pembelian sebesar 7,56 \%

Sehingga Total pengaruh ( Pengaruh langsung dan tidak langsung) variabel Kesadaran merek terdahap Keputusan pembelian sebesar $14,44 \%+7,56 \%=$ 22,00

\section{Besarnya Koefisien Jalur Kemasan, Kesadaran Merek terhadap Keputusan}

\begin{tabular}{|l|l|l|l|l|}
\hline $\begin{array}{l}\mathbf{N} \\
\mathbf{0}\end{array}$ & Variabel & $\begin{array}{l}\text { Pengaruh } \\
\text { langsung }\end{array}$ & $\begin{array}{l}\text { Pengaruh } \\
\text { tiak } \\
\text { langsung }\end{array}$ & $\begin{array}{l}\text { Total } \\
\text { Pengaruh }\end{array}$ \\
\hline $\mathbf{1}$ & Kemasan & 9,00 & 4,77 & 13,77 \\
\hline
\end{tabular}




\section{BIDANG MANAJEMEN}

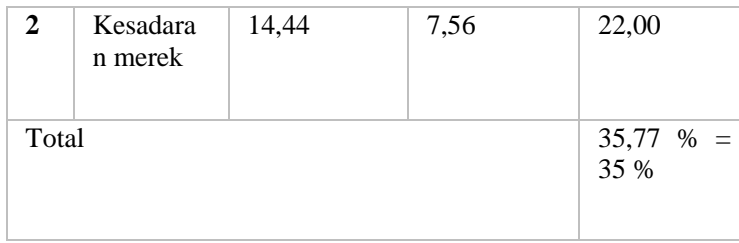

Sumber: Hasil olah data Penelitian, 2014

Dari hasil diatas pengaruh bersama Kemasan dan Kesadaran Merek terhadap Keputusan Pembelian atau nilai koefisien determinasi sebesar $35 \%$ sedangkan sisanya $(100 \%-35 \%)=65 \%$ dipengaruhi oleh faktor lain diluar penelitian ini seperti harga, kualitas dll.

\section{Kesimpulan}

Berdasakan penelitian yang telah dilakukan, maka penulis menarik kesimpulan sebagai berikut:

1. Berdasarkan hasil analisis deskriptif diatas, tanggapan responden mengenai variabel kemasan , keasadaran Merek berada dalam kategori baik. Hal tersebut dapat dilihat dari jawaban responden dan total skor dari itemitem pernyataan yang menggambarkan setiap variabel.

> Adapun Total Skor Tertinggi pada variable kemasan adalah di Indikator bentuk pada pertanyaan "Bentuk Kemasan Nilamsari menarik perhatian "dan terendah ada di indikator logo pada pertanyaan "Merk / Logo mudah dikenali “

$>$ Adapun Total Skor Tertinggi pada variable kesadaran merek adalah di Indikator Ingatan Merek pada pertanyaan "Nilamsari merupakan merk yang terkenal "dan terendah ada di indicator pada hubungan Simbol dengan Merek pada pertanyaan "Logo pada Merk Nilamsari mudah dikenali"

$>$ Adapun Total Skor Tertinggi pada variable keputusan pembelian adalah di Indikator pencarian informasi pada pertanyaan "Saya memiliki rasa penasaran yang tinggi terhadap produk nilamsari "dan terendah ada di indikator pencarian alternatif dengan Merek pada pertanyaan "Produk Nilamsari lebih bagus dibandingkan dengan produk lainnya.

2. Dari hasil uji T yang berfungsi untuk mengetahui besarnya hubungan tiap variabel terbukti secara signifikan adanya Hubungan yang signifikan Antara variable kemasan produk terhadap kesadaran Merek pada Produk kue Nilamsari yang artinya apabila Kemasan Nilamsari di perbaiki maka akan menambah skor terhadap kesadaran Merek Nilamsari begitu juga sebaliknya.

3. Dari hasil pengujian hipotesis secara parsial dengan dilakukannya Uji $\mathrm{T}$, disimpulkan bahwa semua variable berpengaruh signifikan

- Terdapat pengaruh Kemasan yang signifikan terhadap Keputusan pembelian Produk Nilamsari.

- Terdapat pengaruh Kesadaran Mrek yang signifikan terhadap Keputusan pembelian Produk Nilamsari.

Dari hasil pengujian hipotesis secara simultan, disimpulkan bahwa, secara bersama-sama, terdapat pengaruh yang signifikan antara variabel kemasan, dan kesadaran Merek terhadap Keputusan pembelian Produk Nilamsari . Total pengaruh simultan variabel tersebut adalah sebanyak $35 \%$ dan $65 \%$ adalah varibael lain.

\section{Daftar Pustaka}

Aaker, D.A., 1996, 'Measuring brand equity across products and markets', California Management Review 38(3), 102-121. http://dx.doi.org/10.2307/41165845 
Aaker, D.A., 2010, Building strong brands, The Fee Press, New York.

Aaker, D.A., 2011, Building brand relevance, John Boss, San Francisco.

Abedniya, A., 2011, 'The impact of country of origin and ethnocentrism as major dimensions in consumer purchasing behavior in the fashion industry', European Journal of Economics, Finance and Administrative Sciences 21(4), 22-41

Adrian, Payne ,2007. Pemasaran Jasa. Terjemahan Fandi Tjiptono. Andi, Jakarta

Cahyorini, Astri \& Effy Zalfiana 2011. The effect of Packaging Design on Impulsive Buying. Jakarta

Cenadi, Christine Suharto 2000 Peranan Desain Kemasan Dalam Dunia Pemasaran. Jakarta

Chieng Fayrene Y.L. \& Goi Chai Lee,2011,Customer based Barnd equity.serawak.

Dhurup Manilalaa , Chengedzai ,Mafni \& Dumasi, Thepiso 2014 , The Impact of packaging, price and brand awareness on brand loyalty: Evidence from the paint retailing industry. Zambia

Du Toit, Sthepen., Du Toit, Mathilda., Joreskog, K. G., \& Sorbom, D. (1999). Interactive LISREL user's guide. Chichago: Scientific Software International

E. Schumacker, Randall., \& G. Lomax, Richard., (1996). A Beginner's Guide To Structural Equation Modeling. New Jersey: Lawrence Erlbaum Associates.

F. Hair, Joseph., E. Anderson, Rolph., L. Tatham, Ronald., \& C. Black, William. (1998). Multivariate Data Analysis, International Edition 5th Edition. New Jersey: Prentice-Hall International, Inc

Haryanto, J.O., and Hadinoto, A. 2006. "Hubungan Antara Persepsi
Konsumen Terhadap Endorser dan Brand Equity." Journal of Management. Vol.. X No. 01.

Herdiansyah Jefri 2012 , Pengaruh Advertising Terhadap Pembentukan Brand Awareness serta dampaknya pada keputusan Pembelian Produk Kecap Pedas ABC

Hizkia B. Anis S.L.H.V Joyce Lapian Peggy A. Mekel,2014, Atribut Produk dan Bauran Promosi pengaruhnya terhadap keputusan pembelian sepeda motor mio,Manado.

J. Paul Peter dan Olson,Jery C. 2000 Consumer behavior\& Marketing Strategy, Newyork

Joreskog, K. G., \& Sorbom, D. (1993). Structural equation modeling with the SIMPLIS command language. Chichago: Scientific Software International

Joreskog, K. G., \& Sorbom, D. (1996). LISREL 8 user's references guide. Chichago: Scientific Software International

Joreskog, K. G., \& Sorbom, D. (1996). PRELIS 2 user's references guide. Chichago: Scientific Software International

Kotler, Philip dan Gary Armstrong. 2008. Prinsip - Prinsip Pemasaran. Terjemahan Bob Sabran. Jilid 1. Edisi Kedua belas, Penerbit Erlangga, Jakarta.

Kotler, Philip and Kevin L. Keller. 2013. Kotler, Philip and L. Keller, Kevin L.: Marketing Management, 13th edition, Upper Saddle River, NJ: Prentice-Hall,

Kuvykaite,Rita, Dovaliene,Aistè , Navickiene Laura 2009 ,"Impact of package elements on consumer's purchase decision" journal economics and management .Lithuania 
Lasander,Christian,2013.Citra Merek,

Kualitas Produk dan Promosi pengaruhnya terhadap kepuasan konsumen pada

makanan tradisional, Manado.

Lubis, M. Saleh .2013.Pengaruh Ekuitas

Merek terhadap keputusan membeli sepeda motor Yamaha dengan faktor

keluarga sebagai variabel Moderator.

Pasaman Barat

Macdonald, Emma \& Sharp Byron 2010 Management Perceptions of The Importance of Brand Awareness as an indication of Advertising Effectiveness. New York

Massie, Philander Varian 2012 ,Ekuitas merek pengaruhnya terhadap keputusan pembelian xl mobile data service di Kota Manado. Manado

Navickkiene, Dovaliene Laura 2009. Impact of Package Elements on Consumer's Purchase Decision. Rusia

Nitisusastro, Mulyadi. 2012. Perilaku Konsumen. Alfabeta. Bandung. Swastha, Basu dan Irawan. 2002. Manajemen Pemasaran Modern. Penerbit liberty, Yogyakarta.

Oentoro, Deliyanti. 2010. Manajemen Pemasaran Modern. Yogyakarta: LaksBang Pressindo.

Priska N. Pua 2009, Pengaruh bauran Pemasaran jasa Terpadu (8P) terhadap kepuasan konsumen Hotel Sedona Manado. Skripsi, di akses pada April 2013.

Qamariah ,Inneke \& Fadli 2008. Analisis Pengaruh Faktor- Faktor Ekuitas Merek Sepeda Motor Honda Terhadap Keputusan Pembelian. Medan.

Suwarman, Ujang. 2012. Riset Pemasaran Dan Konsumen. Seri 2. IPB Press. Bogor. Stanton. 2002. Pemasaran. Terjemahan jilid 1, Penerbit Salemba Empat, Jakarta.
Santosa, Budi. 2005. Analisis Statistik Dengan Microsoft Excel Dan SPSS. Andi. Yogyakarta.

Schiffman dan Kanuk, 2007. Analisis Prilaku Konsumen. Edisi Pertama BPFE, Yogyakarta.

Simamora, Hendry. 2004. Manajemen Pemasaran Internasional. Jilid 2 Salemba Empat, Jakarta.

Sianturi, Yanina,Erida,Nifita,Ade T.2012 ,Pengaruh Kelompok referensi dan gaya hidup terhadap keputusan menggunakan blackberry, Jambi

Sugiyono. 2010. Metode Penelitian Bisnis. Cetakan Kelima belas. Alfabeta. Bandung.

Sugiyono. 2007. Statistika untuk penelitian. CV Alfabeta. Bandung.

Tjiptono, Fandy. 2008. Strategi Pemasaran. Edisi Ketiga. Andi.Yogyakarta

Tjiptono, Fandy, 2004. Pemasaran Jasa. Edisi Pertama, Bayumedia Publishing. Malang

Umar Husein, 2009. Riset Pemasaran dan Perilaku Konsumen. PT. Gramedia Payne,

Wowor,Valdy, R,2013.Bauran Pemsaran jasa,Pengaruhnya terhadap kepuasan konsumen pengguna mobil avanza veloz PT. Hasjrat Abadi , Manado

Yazid, 2003. Pemasaran Jasa, Konsep dan Implementasi, Edisi Kedua. Sleman, Yogyakarta: EKONISIA. 